\title{
Role of aromatase in sex steroid action
}

\section{E R Simpson}

Prince Henry's Institute of Medical Research, PO Box 5152, Clayton, Victoria 3168, Australia

(Requests for offprints should be addressed to E R Simpson; Email: evan.simpson@med.monash.edu.au)

\section{THE CONCEPT OF LOCAL OESTROGEN BIOSYNTHESIS}

Our understanding of the role of oestrogens in both males and females has expanded greatly in recent years. Hitherto unanticipated roles have emerged that question the very definitions of the terms 'oestrogen' and 'androgen' as they are currently used. Considerable emphasis has been placed on the regulation of extragonadal oestrogen biosynthesis, in particular that which occurs in adipose tissue, bone and brain, and its importance in the well-being of the elderly (Simpson et al. 1997).

Although the ovaries are the principal source of systemic oestrogen in the premenopausal nonpregnant woman, other sites of oestrogen biosynthesis are present throughout the body and these become the major sources of oestrogen beyond menopause. These sites include the mesenchymal cells of the adipose tissue and skin (reviewed in Simpson et al. 1997), osteoblasts (Bruch et al. 1992) and perhaps chondrocytes in bone, vascular endothelial (Bayard et al. 1995) and aortic smoothmuscle cells (Sasano et al. 1999) as well as a number of sites in the brain, including the medial preoptic/anterior hypothalamus, the medial basal hypothalamus and the amygdala (Naftolin et al. 1975). These extragonadal sites of oestrogen biosynthesis possess several fundamental features which differ from those of the ovaries. Principally, the oestrogen synthesised within these compartments is probably biologically active only at local tissue level in a paracrine or 'intracrine' fashion (Labrie et al. 1997a). Thus the total amount of oestrogen synthesised by these extragonadal sites may be small, but the local tissue concentrations achieved are probably quite high and exert signifi-

This commentary was presented at the Symposium on Enzymes and Steroid Hormone Action at the 19th Joint Meeting of the British Endocrine Societies with EFES, March 2000, Birmingham, UK cant biological influence locally. Thus these sources of oestrogen play an important, but hitherto largely unrecognised, physiological and pathophysiological role.

After menopause, adipose tissue becomes the main source of oestrogen (Siiteri \& MacDonald 1973, Simpson et al. 1997). Therefore, in the post-reproductive years, the degree of a woman's oestrogenisation is mainly determined by the extent of her adiposity. This is of clinical importance since corpulent women are relatively protected against osteoporosis (Melton 1997), and the incidence of Alzheimer's disease is lower in more corpulent postmenopausal women than in their slimmer counterparts (V W Henderson, personal communication). Conversely, obesity is positively correlated with breast cancer risk (Huang et al. 1997).

In the case of males, it has been estimated that the testes can account for (at best) $15 \%$ of circulating oestrogens (Hemsell et al. 1974), and local production of oestrogens, both intratesticular and extragonadal, is of physiological significance throughout adult life. For example, the Leydig cells (Tsai-Morris et al. 1985) and other cells of the testes, including germ cells in various stages of differentiation (Nitta et al. 1993), produce oestradiol, which has an important role in spermatogenesis. Oestrogen production in bone appears to be as vital for the maintenance of bone mineralisation and the prevention of osteoporosis in men as it is in women. This is supported by studies of men with either a mutation of the gene encoding the aromatase enzyme (Morishima et al. 1995, Carani et al. 1997) or a mutation of the oestrogen receptor (Smith et al. 1994). These individuals exhibit failure of epiphysial fusion, osteopenia and delayed bone age. Recently, we have observed that male mice with a null mutation in the aromtase gene (ArKO mice), also exhibit alterations in bone histomorphometry characteristic of under-mineralisation (Oz et al. 2000). 
In a similar fashion, it is reasonable to speculate that oestrogen production in one or more brain sites has an influence on sexual behaviour, and (as suggested by recent observational epidemiological studies) may have a role in the maintenance of cognitive function and the prevention of Alzheimer's disease (reviewed in Yaffe et al. 1998). In this context, it is appropriate to reconsider why osteoporosis is more common in women than in men and affects women at a younger age, in terms of fracture incidence. Similarly, it is worth considering why the incidence of Alzheimer's disease is greater among women than among men.

\section{PRECURSOR AVAILABILITY}

A key factor in the gender difference in the incidence of these diseases appears to be the availability of precursor $\mathrm{C}_{19}$ steroids for aromatisation to oestrogens in extragonadal sites - a concept also advanced by Labrie et al. (1998). In postmenopausal women, the principal source of $\mathrm{C}_{19}$ steroid production is the adrenal cortex, which elaborates androstenedione, dehydroepiandrosterone (DHEA) and DHEA sulphate (DHEAS). However, the secretion of these steroids and their plasma concentrations decrease markedly with advancing age (Labrie et al. 1997b). Moreover, DHEA must first be converted to androstenedione prior to aromatisation. Another major step is the reduction of the 17-keto group to 17-hydroxyl, catalysed by 17-hydroxysteroid dehydrogenase (17-HSD) type I, which is essential for formation of the active oestrogen, oestradiol. The distribution of this enzyme in the various extragonadal sites of aromatisation has not yet been fully established, although it is expressed in tumorous breast epithelium (Sasano et al. 1996) and in bone (Sasano et al. 1997). It should be noted in this context that it has been reported that $17-$ HSD type III, which converts androstenedione to testosterone, is present in visceral fat (Corbould et al. 1998), together with 17-HSD type II.

In the male circulation, in contrast, the levels of testosterone are at least an order of magnitude greater than those circulating in the plasma of postmenopausal women. Moreover, they are two orders of magnitude greater than the mean levels of circulating oestradiol in postmenopausal women. Given that much of the circulating oestradiol is bound to sex hormone-binding globulin, it is unlikely to have a major impact on transactivation of the oestrogen receptor, compared with oestrogen produced locally as a consequence of conversion of circulating testosterone. Thus, the uninterrupted sufficiency of circulating testosterone in men throughout life supports the local production of oestradiol by aromatisation of testosterone in oestrogen-dependent tissues, and thus affords ongoing protection against the so-called oestrogen deficiency diseases. This appears to be important in terms of protecting the bones of men against mineral loss and may contribute to the maintenance of cognitive function and prevention of Alzheimer's disease in men.

\section{EXPRESSION OF AROMATASE IN ADIPOSE TISSUE}

Oestrogen biosynthesis is catalysed by aromatase (aromatase cytochrome $\mathrm{P} 450$ ), the product of the CYP19 gene, which is a member of the cytochrome P450 superfamily of genes (reviewed in Simpson et al. 1997). In humans, aromatase expression in the various sites in which it occurs is regulated by tissue-specific promoters through the use of alternative splicing mechanisms. Thus, in the ovary and the testes, expression is mediated by a proximal promoter, promoter II, whose activity is regulated by cyclic AMP (cAMP) and requires both CREB and steroidogenic factor-1 (SF-1). In the placenta, expression is driven by a powerful distal promoter, I.1, whereas in mesenchymal cells of adipose and skin, as well as in osteoblasts, expression is driven by another distal promoter, I.4, which is located between promoters I.4 and II. Transcripts specific for yet another promoter, I.3, are also found in adipose tissue. This promoter is a spliced variant of promoter II, and is also regulated by cAMP.

We have studied aromatase expression in samples of adipose tissue, obtained from women of various ages, using competitive RT-PCR with an internal standard and have found a marked increase in the specific content of $\mathrm{P} 450$ arom transcripts in adipose tissue with increasing age (Bulun \& Simpson 1994), thus providing a molecular basis for the previous observation that the fractional conversion of circulating androstenedione to oestrone increases with age (Hemsell et al. 1974, Edman \& MacDonald 1976). Furthermore, there are marked regional variations in aromatase expression, the highest values being found in adipose tissue from buttocks and thighs as compared with abdomen and breast tissue (Killinger et al. 1987, Bulun \& Simpson 1994).

We also used this RT-PCR technique to examine regional variations in aromatase expression in breast adipose tissue and found that the highest expression occurs in adipose tissue proximal to a tumour, as compared with that distal to a tumour (Bulun et al. 


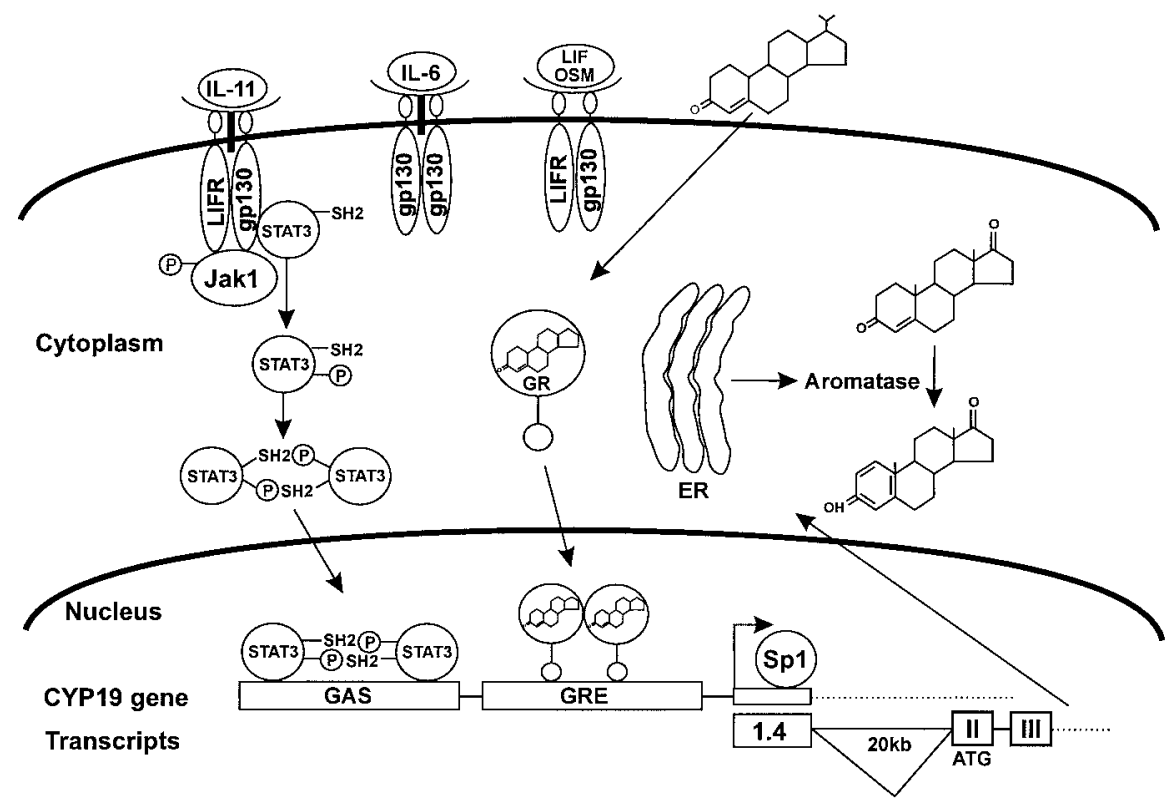

FIGURE 1. Schematic representation of second-messenger signalling pathways whereby Class I cytokines stimulate aromatase gene expression in human adipose stromal cells. Jak1 kinase is bound to the common receptor subunit gp130 and activated following ligand binding and receptor dimerisation, as a consequence of phosphorylation on tyrosine residues. STAT3 is recruited to binding sites on gp130 and is phosphorylated on tyrosine residues by Jak1. These phosphotyrosine residues are recognized by SH2-homology domains on STAT3, resulting in dimerisation followed by translocation to the nucleus and binding to the GAS element of promoter I.4 of the aromatase gene. Following binding of glucocorticoid receptors to the GRE and Sp1 to its site on untranslated exon I.4, activation of transcription of the aromatase gene from promoter I.4 is initiated. Splicing of the initial transcript results in formation of mature mRNA, which translocates to the ribosomes and is translated to give rise to aromatase protein.

1993, Agarwal et al. 1996). This is in agreement with previous observations on the regional distribution of aromatase activity within breast adipose tissue (O’Neill et al. 1988, Reed et al. 1993) as well as observations from an immunocytochemical study (Sasano et al. 1994). These results suggest there is cross-talk between a breast tumour and the surrounding adipose cells, in terms of the ability of the latter to synthesise oestrogens, and that factors produced by developing breast tumours may set up local gradients of oestrogen biosynthesis in the surrounding fat via paracrine mechanisms.

\section{CYTOKINES THAT STIMULATE AROMATASE EXPRESSION IN ADIPOSE TISSUE}

Aromatase is expressed in the stromal mesenchymal cells of adipose tissue (Simpson et al. 1997). These stromal cells grow in culture as fibroblasts and are believed to be preadipocytes. Consequently, these cells have been used in primary culture as a model system to study the regulation of oestrogen biosynthesis in adipose tissue (Price et al. 1992). When serum is present in the culture medium, expression is stimulated by glucocorticoids, including dexamethasone (Ackerman et al. 1981, Simpson et al. 1997). Under these conditions, $\mathrm{P} 450$ arom transcripts contain primarily untranslated exon I.4 at their $5^{\prime}$-ends (Mahendroo et al. 1993). The region of the CYP19 gene upstream of exon I.4 was subsequently characterised (Fig. 1) and found to contain a TATA-less promoter as well as an upstream GRE which is required for expression of reporter gene constructs in the presence of serum and glucocorticoids (Zhao et al. 1995a). Additionally, this region contains a GAS (interferon- $\gamma$ activating sequence) element. Such sequences are known to bind transcription factors of the STAT family (Schindler et al. 1992, Darnell et al. 1994, Zhong et al. 1994).

More recently, it was observed that the effect of serum in stimulating aromatase expression can 
be mimicked by specific factors, namely members of the Class I cytokine family, which includes interleukin-11 (IL-11), IL-6, oncostatin-M (OSM), and leukaemia inhibitory factor (LIF) (Stahl et al. 1994, Zhao et al. 1995b). Members of this cytokine family employ a receptor system involving two different JAK-associated components, gp130 and LIFR $\beta$ or a related $\beta$-component (Stahl \& Yancopoulos 1993). The concentration dependence of the stimulation of aromatase by IL-6, IL-11, LIF and OSM is indicative of high-affinity receptor binding.

The addition of Class I cytokines to adipose stromal cells resulted in a rapid phosphorylation of Jak1 kinase (Zhao et al. 1995b). By contrast, Jak3 kinase was not phosphorylated under these conditions to any significant extent, whereas Jak2 kinase was phosphorylated to an equal extent both in the presence and the absence of IL-11. This phosphorylation occurred on tyrosine residues present in the Jak1 kinase. Both gp130 and LIFR $\beta$ can associate with and activate at least three members of the JAK family, Jak1, Jak2 and Tyk2, but they utilise different combinations of these in different cells (Boulton et al. 1994); however, it is apparent that Jak1 is the kinase of choice in human adipose stromal cells.

This action results in the rapid phosphorylation of STAT3 on tyrosine residues but this was not the case for STAT1. It has been shown that STAT3 is the substrate of choice for the IL-6/LIF/OSM cytokine receptor family and that the specificity of STAT phosphorylation is not based upon which Jak kinase is activated (Stahl \& Yancopoulos 1993, Stahl et al. 1994, Zhao et al. 1995b) but rather is determined by specific tyrosine-based motifs in the receptor components, namely, gp130 and LIFR $\beta$, shared by these cytokines (Boulton et al. 1994, Stahl et al. 1995). Finally, gel shift analysis indicated that STAT3 can interact with the GAS element present in the promoter I.4 region of the P450 arom gene upon the addition of IL-11 to these cells. This interaction, in turn, results in activation of expression, as indicated by transfection experiments employing chimeric constructs in which the -330 / $+170 \mathrm{bp}$ region of the I.4 promoter region was fused upstream of the CAT reporter gene. The results indicate that both deletion of the GAS sequence and mutagenesis of this sequence gave rise to complete loss of IL-11- and serum-stimulated expression in the presence of glucocorticoids.

Activation of this pathway of expression by these cytokines is absolutely dependent on the presence of glucocorticoids. This action of glucocorticoids is mediated by the GRE element downstream of the GAS element (Zhao et al. 1995a). These sequences, though present within a $400 \mathrm{bp}$ region of the gene, are not contiguous, and the nature of the interaction between STAT3, the glucocorticoid receptor and $\mathrm{Sp} 1$ in the regulation of expression of the $\mathrm{P} 450$ arom gene via the distal promoter I. 4 remains to be determined. Our current understanding of the regulation of expression of aromatase in adipose tissue is summarised in Fig. 1.

Tumour necrosis factor $\alpha(\mathrm{TNF} \alpha)$ also stimulates aromatase expression in adipose stromal cells in the presence of dexamethasone. This action of TNF $\alpha$ also involves promoter I.4, specifically an AP1 site upstream of the GAS element that binds a $c$-jun/fos heterodimer upon activation by $\mathrm{TNF} \alpha$ (Zhao et al. $1996 a, b)$. Presumably a MAP kinase pathway is involved in this activation, but this has not yet been delineated.

\section{MESENCHYMAL-EPITHELIAL INTERACTIONS IN REGULATION OF AROMATASE EXPRESSION IN ADIPOSE TISSUE}

As indicated previously, adipose tissue is the major site of oestrogen biosynthesis in elderly women and men. The fact that this expression is confined to the stromal cells rather than the adipocytes themselves is consistent with the known ability of IL-6, IL-11 and TNF $\alpha$ to inhibit the differentiation of 3T3 L1 fibroblasts into adipocytes (Keller et al. 1993). Thus, aromatase is a marker for the undifferentiated fibroblast state.

By employing a competitive RT-PCR technique to measure the levels of the various $\mathrm{P} 450$ arom transcripts in adipose tissue, it was found that in the breast, abdomen, buttocks and thighs of healthy subjects, I.4-containing transcripts predominated, with I.3- and II-specific transcripts being in much lower abundance. On the basis of these findings, it appears that aromatase expression in adipose tissue may be under tonic control by circulating glucocorticoids and that regional and age-dependent variations may be the consequence of paracrine and autocrine secretion of stimulatory cytokines such as IL-6 and TNF $\alpha$, the levels of which have been shown to increase with age (Wei et al. 1992, Daynes et al. 1993) (Fig. 2).

Surprisingly, it was found that the increase in aromatase expression in a tumour-containing breast was due not to an increase in I.4-specific transcripts but rather to an increase in transcripts specific for promoters II and I.3 (Harada et al. 1993, Agarwal et al. 1996). Since expression from these promoters is regulated by cAMP, these results strongly suggest that breast tumours secrete a factor(s) that 

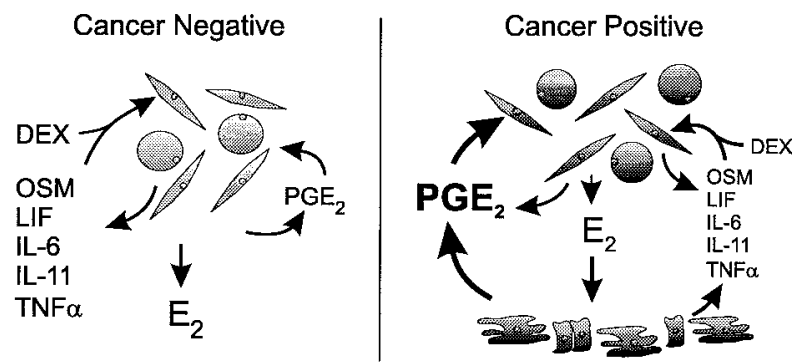

FIGURE 2. Proposed regulation of aromatase gene expression in breast adipose tissue from cancer-free individuals and from those with breast cancer. In the former case, expression is stimulated primarily by Class I cytokines of TNF $\alpha$ produced locally, in the presence of systemic glucocorticoids. As a consequence, promoter I.4-specific transcripts of aromatase predominate. In the latter case, $\mathrm{PGE}_{2}$ produced by the tumorous epithelium, tumour fibroblasts and/or macrophages recruited to the tumour site is the major factor stimulating aromatase expression, as evidenced by the predominance of promoter II-specific transcripts of aromatase.

stimulates aromatase expression in the surrounding stroma by increasing adenylate cyclase. This factor appears to be $\mathrm{PGE}_{2}$ (Zhao et al. 1996a,b). $\mathrm{PGE}_{2}$ is a powerful stimulator of aromatase expression via both PKA and PKC. Both of these pathways are required for maximal expression of aromatase via promoter II in adipose stromal cells (Zhao et al. $1996 a, b)$. Moreover, $\mathrm{PGE}_{2}$ is known to be produced by breast-tumour fibroblasts and epithelium as well as by macrophages recruited to the tumour site (Schrey \& Patel 1995) (Fig. 2).

Such local paracrine mechanisms could be important in the stimulation of breast cancer growth by oestrogens. Commonly, breast tumours produce a desmoplastic reaction whereby there is local proliferation of stromal cells surrounding the tumour, which is strongly indicative of the production of growth factors by the tumour. These proliferating stromal cells express aromatase, as indicated by immunocytochemistry (Sasano et al. 1994). It is possible, then, to propose a positive feedback loop whereby adipose stromal cells surrounding a developing tumour produce oestrogens that stimulate the tumour to produce prostanoids, growth factors and cytokines (Dickson \& Lippman 1987). Some of these act to stimulate the further growth and development of the tumour in a paracrine and autocrine fashion. Additionally, these or other factors act to stimulate proliferation of the surrounding stromal cells and expression of aromatase within these cells. Thus, a positive feedback loop is established by paracrine and autocrine mechanisms, which leads to the continuing growth and development of the tumour (Fig. 2).
Since, in adipose tissue, aromatase is primarily expressed in the mesenchymal stromal cells, we consider it to be a marker of the undifferentiated pre-adipocyte phenotype. The cytokines that stimulate aromatase expression and which are expressed in adipose tissue also inhibit adipocyte differentiation. Thus, factors that stimulate adipocyte differentiation should inhibit aromatase expression. These factors include synthetic PPAR $\gamma$ ligands such as thiazolidinediones, e.g. troglitazone and rosiglitazone (BRL49653) and the endogenous PPAR $\gamma$ ligand 15-deoxy- $\Delta^{12,14}$-prostaglandin $\mathrm{J}_{2}\left(15 \mathrm{~d}-\mathrm{PGJ}_{2}\right)$. Measurement of aromatase activity by RT-PCR/ Southern blotting indicate that these PPAR $\gamma$ ligands inhibit aromatase expression in cultured breast adipose stromal cells stimulated with OSM or TNFa plus dexamethasone in a concentration-dependent manner, whereas a metabolite of troglitazone which does not activate PPAR $\gamma$ has no effect (Rubin et al. 2000). It has also been shown that troglitazone inhibits the luciferase activity of reporter constructs containing various lengths of the upstream region of promoter I.4 transfected into mouse 3T3-L1 pre-adipocyte mesenchymal cells, whereas the troglitazone metabolite does not. Since local oestrogen production in breast fat is implicated in breast cancer development in postmenopausal women, the actions of PPAR $\gamma$ ligands suggest they may have a potential therapeutic benefit in the treatment and management of breast cancer.

\section{CLINICAL CONSIDERATIONS}

This local stimulation of aromatase expression within the tumour and surrounding mesenchymal tissue is such that intratumoral oestradiol levels are at least an order of magnitude greater than those in the circulating plasma of postmenopausal women (Pasqualini et al. 1996). An important issue pertaining to the role of oestrogen in the development of breast cancer in postmenopausal women is the relationship between hormone-replacement therapy (HRT) and breast cancer risk. An extensive metaanalysis of a large body of the available epidemiological data found that systemic administration of oestrogen with/without progestin to postmenopausal women is associated with an overall 1.35-fold increase in breast cancer risk (Collaborative Group on Hormonal Factors in Breast Cancer 1997). The increase in risk was reported to be greater in women of very low body mass index (BMI) but diminished with increasing BMI and was negated by obesity. This reinforces the hypothesis that high local concentrations of oestradiol (Pasqualini et al. 1996) as a consequence of synthesis within the breast 
stimulate cancer development, and that the increase in circulating plasma oestrogen as a consequence of HRT has little influence on intratumoral levels except in women with minimal adiposity. The action of locally produced oestrogen appears to be largely paracrine in nature and mediated via the classical oestrogen receptor(s) or else via DNA adduct formation by quinone intermediates (Service 1998).

In conclusion, we believe that the results of recent studies reveal the significance of local oestrogen production in the physiology and pathophysiology of elderly women, and, in particular, its importance in the development of breast cancer and in the maintenance of bone mineralisation. Local oestrogen production may also play a role in the prevention of cardiovascular disease and in the maintenance of cognitive function. These studies not only throw light on the role of locally produced oestrogens in health and disease processes, but may also lead to new and hitherto unexpected modalities of therapy. This is already apparent from the observation that tumour-derived $\mathrm{PGE}_{2}$ appears to be a major factor stimulating local aromatase expression in the breast fat of cancer patients (Schrey \& Patel 1995, Zhao et al. 1996a,b) (Fig. 2), which leads to the consideration that prostaglandin synthesis inhibitors (such as aspirin and ibuprofen) may be beneficial in breast cancer prevention or treatment (Harris et al. 1996). Similarly, the observation that PPAR $\gamma$ ligands, namely the thiazolidinediones, inhibit aromatase expression suggests that these compounds, which have been used in the USA for the treatment of insulinresistant diabetes, may also have a role in breast cancer prevention.

Third-generation aromatase inhibitors are proving useful in the treatment of oestrogen-dependent diseases such as breast cancer and, more recently, endometriosis (Bulun et al. 1999). However, they have the disadvantage that they inhibit aromatase activity in a global fashion and thus could have a detrimental impact at sites where oestrogen is required for normal function, such as in the maintenance of bone mineralisation and possibly the maintenance of cognitive function in the brain. The concept of selective aromatase modulators (SAMs) is made possible by three considerations presented here. The first of these is that in postmenopausal women and in men, oestrogen is not a significant circulating hormone but instead acts at a local level in the sites where it is produced, in a paracrine or even 'intracrine' fashion. Secondly, aromatase expression in these different tissue sites of expression is regulated by the use of tissue-specific promoters. Thirdly, the various tissue-specific aromatase promoters employ entirely different signalling pathways and thus different cohorts of transcription factors. Thus it is possible to envisage tissue-specific inhibition of aromatase expression in a fashion similar to that of tissue-specific regulation of oestrogen action (the SERM concept). In view of the fact that Tamoxifen and other possible SERMs are not generally efficaceous for an indefinite period of time, SAMs could provide a parallel, alternative treatment, either as a backup or as a first-line modality.

\section{ACKNOWLEDGEMENTS}

This work was supported by the Victorian Breast Cancer Research Consortium Inc., by Project Grant No. 981126 from the National Health \& Medical Research Council (Australia) and by Grant No. AGO8174 from the National Institute of Aging (USA). The authors thank Sue Elger for skilled editorial assistance.

\section{REFERENCES}

Ackerman GE, Smith ME, Mendelson CR, MacDonald PC \& Simpson ER 1981 Aromatisation of androstenedione by human adipose tissue stromal cells in monolayer culture. Fournal of Clinical Endocrinology and Metabolism 53 412-417.

Agarwal VR, Bulun SE, Leitch M, Rohrich R \& Simpson ER 1996 Use of alternative promoters to express the aromatase cytochrome P450 (CYP19) gene in breast adipose tissues of cancer-free and breast cancer patients. Fournal of Clinical Endocrinology and Metabolism 81 3843-3849.

Bayard F, Clamens S, Delsol G, Blaes N, Maret A \& Faye 1995 Oestrogen biosynthesis, oestrogen metabolism and functional oestrogen receptors in bovine aortic endothelial cells. Ciba Foundation Symposium 191 122-132.

Boulton TG, Stahl NS \& Yancopoulos GD 1994 Ciliary neurotrophic factor/leukemia inhibitory factor/interleukin 6/oncostatin M family of cytokines induces tyrosine phosphorylation of a common set of proteins overlapping those induced by other cytokines and growth factors. Fournal of Biological Chemistry 269 11648-11655.

Bruch HR, Wolf L, Budde R, Romalo G \& Schweikert HU 1992 Androstenedione metabolism in cultured human osteoblast-like cells. Fournal of Clinical Endocrinology and Metabolism 75 101-105.

Bulun SE \& Simpson ER 1994 Competitive RT-PCR analysis indicates levels of aromatase cytochrome P450 transcripts in adipose tissue of buttocks, thighs, and abdomen of women increase with advancing age. Fournal of Clinical Endocrinology and Metabolism 78 428-432.

Bulun SE, Price TM, Mahendroo MS, Aitken J \& Simpson ER 1993 A link between breast cancer and local oestrogen biosynthesis suggested by quantification of breast adipose tissue aromatase cytochrome $\mathrm{P} 450$ transcripts using competitive polymerase chain reaction after reverse transcription. Fournal of Clinical Endocrinology and Metabolism 77 1622-1628.

Bulun SE, Zeitoun KM, Takayama K, Simpson ER \& Sasano H 1999 Aromatase as a therapeutic target in endometriosis. Trends in Endocrinology and Metabolism 11 22-27. 
Carani C, Qin K, Simoni M, Fanstini-Fustini M, Serpanti S, Boyd J, Korach K \& Simpson ER 1997 Aromatase deficiency in the male: effect of testosterone and oestradiol treatment. New England Fournal of Medicine 337 91-95.

Collaborative Group on Hormonal Factors in Breast Cancer 1997 Collaborative re-analysis of data from 51 epidemiological studies of 52705 women with breast cancer and 108441 women without breast cancer. Lancet 350 1047-1059.

Corbould AM, Judd SJ \& Rodgers RJ 1998 Expression of types 1, 2 and 317 beta-hydroxysteroid dehydrogenase in subcutaneous abdominal and intra-abdominal adipose tissue in women. Fournal of Clinical Endocrinology and Metabolism 83 187-194.

Darnell JE Jr, Kerr IM \& Stark GR 1994 Jak-STAT pathways and transcriptional activation in response to IFNs and other extracellular signaling proteins. Science 264 1415-1420.

Daynes RA, Araneo BA, Ershler WB, Maloney C, Li GZ \& Ryu SY 1993 Altered regulation of IL-6 production with normal aging. Possible linkage to the age-associated decline in dehydroepiandrosterone and its sulfated derivative. Fournal of Immunology 150 5219-5230.

Dickson RB \& Lippman ME 1987 Oestrogenic regulation of growth and polypeptide growth factor secretion in human breast carcinoma. Endocrine Reviews 8 29-43.

Edman CD \& MacDonald PC 1976 The role of extraglandular oestrogen in women in health and disease. In The Endocrine Function of the Human Ovary, pp 135-140. Eds JM Serio \& G Giusti. London: Academic Press.

Harada N, Utsume T \& Takagi Y 1993 Tissue-specific expression of the human aromatase cytochrome $\mathrm{P} 450$ gene by alternative use of multiple exons 1 and promoters, and switching of tissue-specific exons 1 in carcinogenesis. PNAS $9011312-11316$

Harris RE, Nauboodim KK \& Farrar WK 1996 Nonsteroidal anti-inflammatory drugs and breast cancer. Epidemiology 1 203-205.

Hemsell DL, Grodin JM, Brenner PF, Siiteri PK \& MacDonald PC 1974 Plasma precursors of oestrogen. II. Correlation of the extent of conversion of plasma androstenedione to oestrone with age. Fournal of Clinical Endocrinology and Metabolism 38 476-479.

Huang Z, Hankinson SE, Colditz GA, Stampfner MJ, Hunter DJ, Manson JE, Hennekens CH, Rosner B, Speizer FE \& Willett WC 1997 Dual effects of weight and weight gain on breast cancer risk. Fournal of the American Medical Association 278 1407-1411.

Keller DC, Du XX, Srour EF, Hoffman R \& Williams DA 1993 Interleukin-11 inhibits adipogenesis and stimulates myelopoiesis in human long-term marrow cultures. Blood $\mathbf{8 2}$ 1428-1435.

Killinger DW, Perel E, Daniilescu D, Kherlip LV \& Lindsay WRN 1987 The relationship between aromatase activity and body fat distribution. Steroids 50 61-72.

Labrie F, Belanger A, Cusan L \& Candas B $1997 a$ Physiological changes in dehydroepiandrosterone are not reflected by serum levels of active androgens and oestrogens but by their metabolites: intracrinology. Fournal of Clinical Endocrinology and Metabolism 82 2403-2409.

Labrie F, Belanger A, Cusan L, Gomez JL \& Candas B $1997 b$ Marked decline in serum concentrations of adrenal C19 sex steroid precursors and conjugated androgen metabolites during aging. Fournal of Clinical Endocrinology and Metabolism 82 2396-2402.

Labrie F, Belanger A, Luu-The V, Labrie C, Simond J, Cusan L, Gomez JL \& Candas B 1998 DHEA and the intracrine formation of androgens and oestrogens in peripheral target tissues: its role during aging. Steroids $\mathbf{6 3}$ 322-328.
Mahendroo MS, Mendelson CR \& Simpson ER 1993 Tissue-specific and hormonally-controlled alternative promoters regulate aromatase cytochrome $\mathrm{P} 450$ gene expression in human adipose tissue. Fournal of Biological Chemistry 268 19463-19470.

Melton LJ 1997 Epidemiology of spinal osteoporosis. Spine 22 $2 \mathrm{~S}-11 \mathrm{~S}$.

Morishima A, Grumbach MM, Simpson ER, Fisher C \& Qin K 1995 Aromatase deficiency in male and female siblings caused by a novel mutation and the physiological role of oestrogens. Fournal of Clinical Endocrinology and Metabolism $803689-3698$.

Naftolin F, Ryan KJ, Davies IJ, Reddy VV, Flores F, Petro Z, Kuhn M, White RJ, Takaoka Y \& Wolin L 1975 The formation of estrogens by central neuroendocrine tissues. Recent Progress in Hormone Research 31 295-319.

Nitta H, Bunick D, Hess RA, Janulis L, Newton SC, Millette CF, Osawa Y, Shizuta Y, Toda K \& Bahr JM 1993 Germ cells of the mouse testis express $\mathrm{P} 450$ aromatase. Endocrinology 132 1395-1401.

O’Neill JS, Elton RA \& Miller WR 1988 Aromatase activity in adipose tissue from breast quadrants: a link with tumour site. British Medical Fournal 296 741-743.

Oz OK, Zerwekh J, Fisher CR, Graves KN, Nanu L, Millsaps R \& Simpson ER 2000 Bone has a sexually dimorphic response to aromatase deficiency. Fournal of Bone and Mineral Research 15 507-514.

Pasqualini JR, Chetrite G, Blacker C, Feinstein MC, De la Londe L, Talbi M \& Maloche C 1996 Concentrations of oestrone, oestradiol and oestrone sulfate and evaluation of sulfatase and aromatase activities in pre- and postmenopausal breast cancer patients. Fournal of Clinical Endocrinology and Metabolism 81 1460-1464.

Price T, Aitken J, Head J, Mahendroo MS, Means GD \& Simpson ER 1992 Determination of aromatase cytochrome P450 messenger RNA in human breast tissues by competitive polymerase chain reaction (PCR) amplification. Fournal of Clinical Endocrinology and Metabolism $\mathbf{7 4}$ $1247-1252$.

Reed MJ, Topping L, Woldham NG, Purohit A, Ghilchik MW \& James VHT 1993 Control of aromatase activity in breast cancer cells: the role of cytokines and growth factors. Fournal of Steroid Biochemistry and Molecular Biology 44 589-596.

Rubin GL, Zhao Y, Kalus AM \& Simpson ER 2000 PPAR $\gamma$ ligands inhibit oestrogen biosynthesis in human breast adipose tissue - possible implications for breast cancer therapy. Cancer Research 60 1604-1608.

Sasano H, Nagura H, Harada N, Goukon Y \& Kimura M 1994 Immunolocalization of aromatase and other steroidogenic enzymes in human breast disorders. Human Pathology 25 530-535.

Sasano H, Frost AR, Saitoh R, Harada N, Poutanen M, Vihko R, Bulun SE, Silverberg SG \& Nagura H 1996 Aromatase and $17 \beta$-hydroxysteroid dehydrogenase Type 1 in human breast carcinoma. Fournal of Clinical Endocrinology and Metabolism 81 4042-4046.

Sasano H, Uzuki M, Sawai T, Nagura H, Matsunaga G, Kashimoto O \& Harada N 1997 Aromatase in human bone tissue. Fournal of Bone and Mineral Research 12 1416-1423.

Sasano H, Murakami G, Shizawa S, Satomi S, Nagura H \& Harada N 1999 Aromatase and sex steroid receptors in human vena cava. Endocrine Fournal 46 233-242.

Schindler C, Fu X-Y, Improta T, Aebersold R \& Darnell JE Jr 1992 Proteins of transcription factor ISGF-3: one gene encodes the 91 - and $84 \mathrm{kDa}$ ISGF- 3 proteins that are activated by interferon alpha. PNAS 89 7836-7839. 
Schrey MP \& Patel KV 1995 Prostaglandin $E_{2}$ production and metabolism in human breast cancer cells and breast fibroblasts. Regulation by inflammatory mediators. British Fournal of Cancer 72 1412-1419.

Service RF 1998 New role for oestrogen in cancer? Science 279 1631-1633.

Siiteri PK \& MacDonald PC 1973 Role of extraglandular oestrogen in human endocrinology. In Handbook of Physiology, vol 2, pp 619-629. Eds RO Greep \& EB Astwood. Washington: American Physiology Society.

Simpson ER, Ackerman GE, Smith ME \& Mendelson CR 1981 Oestrogen formation in stromal cells of adipose tissue of women: induction by glucocorticosteroids. PNAS $\mathbf{7 8}$ $5690-5694$.

Simpson ER, Zhao Y, Agarwal VR, Michael MD, Bulun SE, Hinshelwood MM, Gramah-Lorence S, Sun S, Fisher T \& Mendelson CR 1997 Aromatase expression in health and disease. Recent Progress in Hormone Research 52 185-213.

Smith EP, Boyd J, Frank GR, Takahashi H, Cohen RM, Specker B, Williams TC, Lubahn DB \& Korach KS 1994 Oestrogen resistance caused by a mutation in the oestrogen-receptor gene in a man. New England Fournal of Medicine 331 1056-1061.

Stahl N \& Yancopoulos GD 1993 The alphas, betas and kinases of cytokine receptor complexes. Cell 74 587-590.

Stahl N, Boulton TG, Farruggella T, Ip NY, Davis S, Witthuhn BA, Quelle FW, Silvenoinen O, Barbieri G, Pellegrini S, Ihle JN \& Yancopoulos GD 1994 Association and activation of Jak-Tyk kinases by CNTF-LIF-OSMIL-6 beta receptor components. Science 263 92-95.

Stahl N, Farruggella T, Boulton TG, Zhong Z, Darnell JE \& Yancopoulos GD 1995 Modular tyrosine-based motifs in cytokine receptor specific choice of STATs and other substrates. Science 267 1349-1353.
Tsai-Morris CH, Aquilana DR \& Dufau ML 1985 Cellular localization of rat testicular aromatase activity during development. Endocrinology 116 38-46.

Wei J, Xu H, Davies JL \& Hemmings GP 1992 Increase of plasma IL-6 concentration with age in healthy subjects. Life Sciences 51 1953-1956.

Yaffe K, Sawaya G, Lieberburg L \& Grady D 1998 Oestrogen therapy in postmenopausal women: effects on cognitive function and dementia. Fournal of the American Medical Association 279 688-695.

Zhao Y, Mendelson CR \& Simpson ER 1995 a Characterization of the sequences of the human CYP19 (aromatase) gene that mediate regulation by glucocorticoids in adipose stromal cells and fetal hepatocytes. Molecular Endocrinology 9 340-349.

Zhao Y, Nichols JE, Bulun SE, Mendelson CR \& Simpson ER $1995 b$ Aromatase P450 gene expression in human adipose tissue. Role of a Jak/STAT pathway in regulation of the adipose-specific promoter. Fournal of Biological Chemistry 270 16449-16457.

Zhao Y, Agarwal VR, Mendelson CR \& Simpson ER $1996 a$ Oestrogen biosynthesis proximal to a breast tumour is stimulated by $\mathrm{PGE}_{2}$ via cyclic AMP, leading to activation of promoter II of the CYP19 (aromatase gene). Endocrinology $1375739-5742$.

Zhao Y, Nichols JE, Valdez R, Mendelson CR \& Simpson ER $1996 b$ Tumour necrosis factor- $\alpha$ stimulates aromatase gene expression in human adipose stromal cells through use of an activating protein-1 binding site upstream of promoter I.4. Molecular Endocrinology 10 1350-1357.

Zhong Z, Wen Z \& Darnell JE 1994 Members of the family of signal transducers and activators of transcription. PNAS 91 4806-4810.

RECEIVED 10 April 2000 